\title{
Human Rights in the Context of Criminal Justice: A Study of Urban Crime
}

\author{
Randriamihanta Jery Elis*, Yideng Liu \\ Department of Law, Central South University, Changsha, China \\ Email: ^2647090998@qq.com
}

How to cite this paper: Elis, R. J., \& Liu, Y. D. (2018). Human Rights in the Context of Criminal Justice: A Study of Urban Crime. Open Journal of Political Science, 8, 305-315.

https://doi.org/10.4236/ojps.2018.83022

Received: July 4, 2018

Accepted: July 27, 2018

Published: July 30, 2018

Copyright (๑) 2018 by authors and Scientific Research Publishing Inc. This work is licensed under the Creative Commons Attribution International License (CC BY 4.0).

http://creativecommons.org/licenses/by/4.0/

(c) (i) Open Access

\begin{abstract}
Urban areas are known by their facilities and enhanced opportunities of living and employment. With the availing all the facilities, many serious issues have emerged due to urbanization in developing countries. The most highlighted problems include security and crime in urban areas in developing countries. This paper is aimed to focus on the urban crime, the reasons behind the crime happened, the major indicators of crimes and what is the city response and what policy should be developed by police and society. To achieve the objective of this research secondary data was used. With the help of literature crime indicators were explored and explained well in this research. Eight countries were analyzed with the help of literature to check the overall crime situation there. Crime in those all eight countries was low to high level. It is in alarming in some areas of Africa and other developing countries. Study showed crime is increasing from last three years which is high. In any society urban crime prevails it created unsafe environment, threaten to lives, threaten to belonging and has impact on life quality and economy of the country. Law force agencies must be empowered and well equipped to control the situation. It's government responsibilities to create employment opportunities for youth so that they cannot engage into illegal activities.
\end{abstract}

\section{Keywords}

Urban Crime, Urbanization, Security Issues in Developing Countries

\section{Introduction}

Urbanization refers to the concept when people move to urban areas from remote areas in search of better quality of life. This concept is more prevalent in those regions of the world where rural areas are quite neglected especially in de- 
veloping countries. Certain factors are responsible for this movement like migrants expect better employment opportunities in urban areas (Heyer, Roberts, \& Williams, 1981; Knight \& Gunatilaka, 2017) or it is the comfortable environment and attraction for wealth (Harris \& Todaro, 1970). Besides the presence of facilities, many issues have emerged due to urbanization. Most highlighted problems are of security and crime (Ahmed \& Salihu, 2013; Tretter, 2013). There are different concepts of crime. Various researchers have defined crime in different perspectives. Habibullah, Baharom, \& Tan (2013) defined crime as the violation of property rights. Most suitable definition of crime is given by Tenibiaje (2010) which states that "deviant behaviour that violates prevailing norms, which may be cultural, social, political, psychological and economic conditions". From the perspective of criminal law, crime is the any act which is forbidden by law (Usman, Yakubu, \& Bello, 2012). Usman et al. (2012) also provided four categories of crime as: 1) crimes against person; 2) crimes against property; 3 ) crimes against lawful authority and 4) crimes against local act.

Urbanization is a procedure whereby towns raise naturally or due to migrants become urban. Harris and Todaro (1976) described it as "proceeds in response to urban-rural differences in expected earning". Migrants taught they may secure job and get good employments in urban areas. The word crime and its perception and meaning are different. Some different geographical positions for example prostitution and homosexuality are crime in some countries and regions while is legal in some areas too. A few decades ago, dumping toxic waste has not been classified as a crime but presently it is a serious crime and violation of laws in country like Nigeria (Dambazau, 2007). So, crime varies from time to time and by location and culture. It is same for criminal behaviour, but certain cultures have higher criminal actions than others and difference can be initiated in the same society (urban areas), where criminal actions are prevalent in some places over others. Within the same city, criminal actions incline to be advanced in the city centres than in the suburbs (Soh, 2012). In this framework, crime states to defilement of state laws or different acts forbidden by state laws that are subjected to penalty in harmony to the set of the laws.

These comprise all types of divergent acts or offences against government, against local act, against property and against person. The main objective of this study was to elaborate different types of crime in urban life of developing countries, reasons and its impacts on the life of local people and national level, due to time and data limitation, this study was limited to some countries. Urban crime situation was analyzed among developing countries. This study was based on secondary data like research article, newspapers, Government reports and related materials. As have been presented in many literatures, there are basically two approaches of data collection in research: primary data collection (fieldwork) and secondary data collection (desk study). Methodology used in this paper is more qualitative than quantitative in nature. The present study used available data from previous studies (Ajaegbu, 2012; Katsina, 2013). The first 
and foremost aim of this study was to check variables of urban crimes, reasons of crimes and its impacts on people lives in eight countries. The article is organized as follows started from literature, urban crimes, reasons of urban crimes, in the present study, some developing countries were selected for to check the situation related to urban crime there. In literature some articles can find related to urban crimes and its impact on people lives, but this article is different in its nature, it covers more countries, moreover, it is a review article and totally depends on existing literature.

\section{Urban Crimes}

It is a common perception among all criminologist that crime rate is high in urban areas than rural areas. Although there is different crimes and different crimes ratio at different places in different urban area, but questions for criminologist is that what is the reason of this variation. What are the reasons some urban areas experience high level of crime while other neighboring areas enjoy less level of crime? In some studies criminologist tried to find answer of these questions with the help of correlation of crimes rates and variables. In line with social inefficiency, most research of this type emphases on city or neighborhood features connected with high crime levels in an area. Though the variety of correlates deliberate is quite wide, the most common features include socioeconomic and demographic characteristics of areas for example racial composition, poverty level, age structure, residential mobility, Management Issues, Political forces, labor force characteristics, and divorce rate. There are number of articles explained correlation in these indicators but there is not a singular reason that can be reason of urban crime, different types of crimes are due to different types of people and at different time and circumstances (Dambazau, 2007).

\section{Reasons of Urban Crimes}

Urban crime is a bad evil, it is not only a big challenge for developing nations but developed nations are also facing it. There can be number of reasons for people to choose criminal activities. Following are some reasons of Urban Crimes.

\subsection{Population}

As per Population Reference Bureau, the world population of 2015 stands at 7.3 billion, while $53 \%$ are living in urban areas; it is estimated that about 9.8 billion world populaces in 2050 out of which $69 \%$ will be urban. As per another censes PRB 2017 world population of 2017 is 7.5 billion, of which urban population is $54 \%$. This rise in population is linked with increase in crimes rate as people endure in pathetic state of existing even in urban areas, due to shortage of resources. This is a one of the reason of urban crime and environmental pollutions in urban area (Sohail et al., 2014). Urbanization is good and bad if it became reason of crime especially in developing countries. Ultimately rapid growth in urbanization had a direct relationship with the increase in crime as the rate of 
unemployment had been on the increase, high cost of living coupled with housing problem (homelessness) and these in turn led to all sorts of urban problems crime inclusive (Usman, Yakubu, \& Bello, 2012; Amin, 2014). Urban areas are the places where people of different culture background live together. Soh (2012) opines that all 'forms of deviance flourish within urban environments because there are more individuals who support this subculture'. These sub-cultures led to pledging various crimes in urban areas and continuous rise in crime in such areas are correlated with the fast development in urbanism. Many researchers believed that crime is associated with population growth in urban areas.

\subsection{Unemployment}

As per some researcher poverty and unemployment is the main cause of criminal behavior (Usman, Yakubu, \& Bello, 2012; Ajaegbu, 2012). In some African country high rate of unemployment and financial issue reported as a main case of crime (Ajaegbu, 2012). As per Soh (2012) criminal behavior can be find in all types of people even rich people can be involved in criminal activities. As its common phenomena people migrates to cities for to seek good employment opportunities especially in developing countries. Because it's easy to get more job and better life in urban areas. This phenomenon developed rapidly, particularly in Africa and Asian sub-regions where people from neglected rural areas migrate to the urban areas expecting employment and better living conditions. In poor countries, situations do not support urbanized area, due to this people get involved in criminal activities to fulfill their daily desires (Ajaegbu, 2012). Many researchers tried to find out relationship between crime and unemployment, some of them find positive relationship among them but some of them were unable to prove positive association among these variables. Inspections that go beyond the simple deliberation of employed against unemployed persons have found that areas with unbalanced unemployment situations for relatively large portions of adults have higher crime rates.

\subsection{Poverty}

In Literature relationship between rich and crime is very few but relationship between poor and crime is higher. The relationship between crime and poverty was find in University of Chicago, where Sahw and McKay compared delinquency ate in some cities, they found high and significant relation between these variables racial heterogeneity, mobility and poverty, poverty as a most important factor. Over the decades, many aggregate studies have empirically reinforced the poverty and crime connection. Many of these researches have observed the uppermost crime rates within the poorest urban slums (Patterson, 1991). A connection between economic conditions and crime has also been found at higher heights of aggregation, such as states and cities. Many foremost criminologists trust that the poverty-crime connection is direct and clear (Hipp, 2007). Messner (1982) observed the relationship between inequality, poverty, 
and fierce crime. Messner verified whether comparative poverty is more significant than absolute poverty for amplification crime. What Messner realizes is quite astonishing. While his economic amount of family income disparity shows to be insignificant, his second economic measure, size of the poverty population, exhibits a significant negative correlation with the homicide rate. That is, the size of the needy population is contrarywise related to the homicide rate. Poverty upsurges high cost of almost every item of living, from domestic to health. Such monetary hardships lead to upsurge in crime rates (Soh, 2012).

\subsection{Political Forces}

Political factors directly influence crime rate in urban areas. Bad governance creates inequality among people which lead to unemployment and social inequalities (Ajaegbu, 2012). So, it has become most important factor of urban crime. Such kind of forces may include their policies, bad governess, weak law or problem in implementation of law and justice system (Simon, 2017). All these may lead to marginalization of convinced sections of society. It can have more directly in different ways like failure of leadership or bad governance, in many characteristics, is responsible for deprived economic growth planning and establishing inequitable mechanisms for the distribution of national resources or wealth, and in turn generate unemployment and social inequality. At the same time some other reason like bribery, corruption, poor governance and lack of policy initiatives in developing countries (Scheingold, 1995).

\subsection{Implementation of Law and Management Issues}

It became easier for criminals if law enforcement agencies are weak or lack of implementation of strong rules and law. It approved by research that crime control agencies provide more space to enhance their criminal activities (Ghani, 2017). Urban sustainability and stability has been associated to safety of securing and monitoring of urban zones. Problems of personal security became connected with urban "quality of life" and "livability" and talking crime has become a significant standard for a city's excellence of life (England \& Simon, 2010). In realism, the best tactic to crime management is crime prevention that is to stop crime before it occurs. This means obstructive all chances or avenues for crime to be dedicated, then criminals will be expatriate and muddled. This is one of the best and appropriate way to control crime. Seemingly, crime anticipation involved any strategy that intended at reducing or removing the bulge level of criminal activities, risk of dwindling and fear of existence a crime victim. It is always quantified that prevention is well than cure. So, most appropriate way is to prevent the illegal acts before they occur. Absence of proper management in relaxing migrants to urban areas is the crucial features in urban crimes. Reducing crime and fear of crime can improve the quality of life, which is a crucial issue in producing developments that are more maintainable. As some countries strained to tool some plans to control urban crime. 


\subsection{Lack of Resources}

Collapsing infrastructure. Many cities in the developing world do not have an infrastructure that is capable of dealing with the massive increases in population. In addition, the governments do not have sufficient funds available to maintain the facilities. That is the reason which literature approved its easy to do criminal activities in developing and poor countries, while developed and with sufficient resources these countries are able to control crime situation (Sampson \& Groves, 1989).

\subsection{Freedom of Armed Uses}

This is also one of main factor in developing countries, use of armed by people that can be licensed or unlicensed. Which create unhealthy and unbalance environmental with the region. This free use of armed can be used in target killing, theft and even for suicides (Greenwood, 1972).

\section{Discussion}

Urban safety indicators were developed from an extensive literature review. The aim is to standardize the measurement and assessment of the state of safety across cities, and thereby assist city governments to identify the key determinants and mitigating factors of crime and violence, and so can develop appropriate crime prevention policies and strategies. The factors that contribute to urban crime and safety are conceptualized as interlinked layers, as shown in Figure 1. This Figure explained well about crimes types and strategy about how to control urban crime.

International Collegiate Programming Contest (ICPC) is a multitier, team-based, programming competition, headquartered at Baylor University. They conducted a survey regarding safety gender gap in different countries. They came with result that New Zealand is the country where men feel secure at night while Germany is a country where female feel secure while going outside at night. New Zealand and Germany both countries are in the list of developed countries Table 1. Numbeo is the world's largest database of user contributed data about cities and countries worldwide. Numbeo provides current and timely information on world living conditions including cost of living, housing indicators, health care, traffic, crime and pollution. Table 1 showed the situation of walking alone during day and night time among eight selected countries, as per this data walking during day time is moderate to very high mean usually people feel secure while day time. On the other hand, situation at night is worse from very low to moderate, which is alarming, people feel unsecure at night time while walking outside among all these mentioned countries while situation in Madagascar is very worst Table 1.

World population is increasing, it's a big challenge to provide all facilities to people and control urban crime. Urban crime is everywhere in the world in developed and developing countries, some countries due to reliable resources can manage it properly but some facing it and it creates a negative environment with 


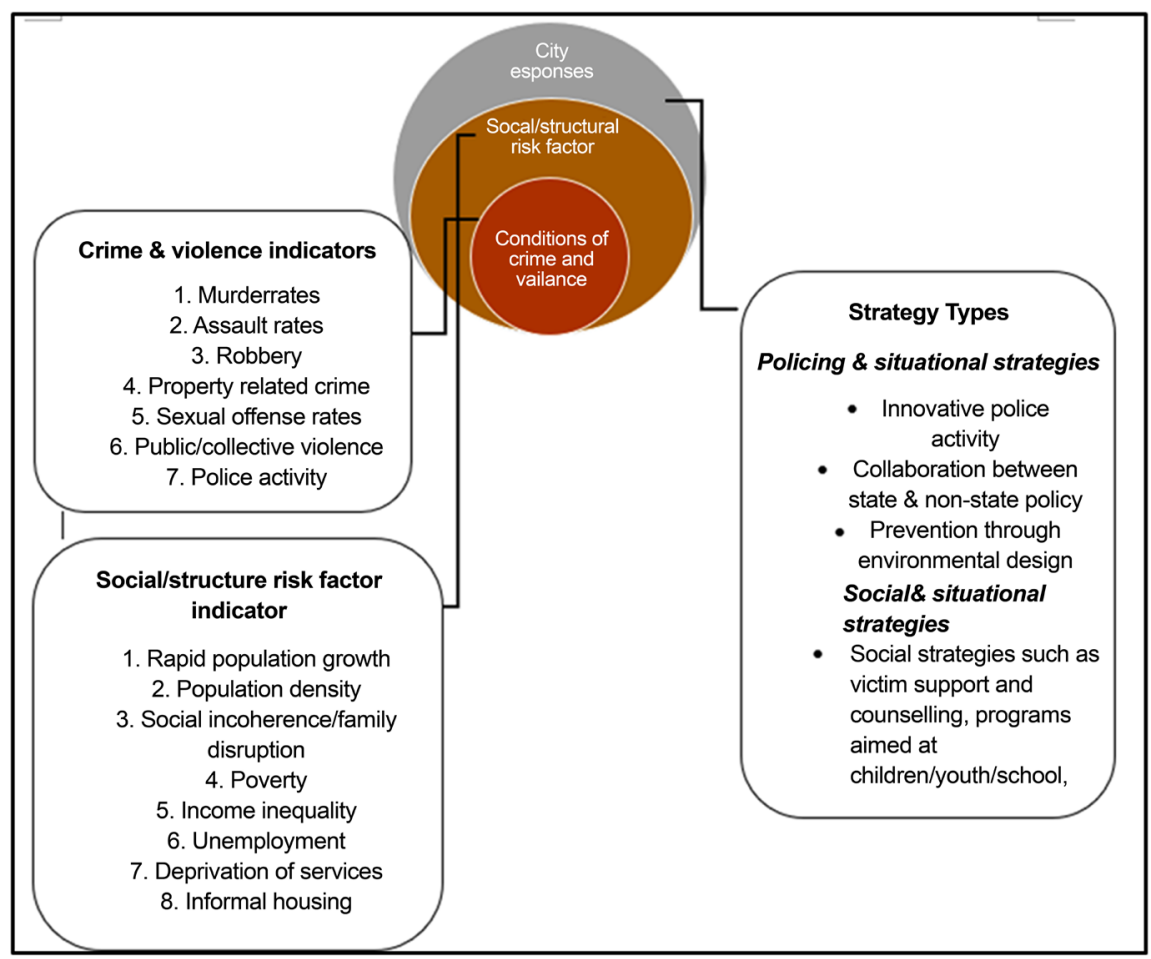

Figure 1. Factors indicators towards urban crime and city response. (Source: Urban safety in South Africa report, 2017) (SACN, 2017).

Table 1. Safety gender gap in different countries (Source: ICPC, 2014).

\begin{tabular}{|c|c|c|c|}
\hline \multirow{2}{*}{$\begin{array}{l}\text { Sr. } \\
\text { No. }\end{array}$} & \multirow{2}{*}{ Countries } & \multicolumn{2}{|c|}{ Percentage of people feeling safe at night } \\
\hline & & Men & Women \\
\hline 1 & New Zealand & 85 & 50 \\
\hline 2 & Algeria & 66 & 32 \\
\hline 3 & Cyprus & 85 & 57 \\
\hline 4 & Italy & 68 & 40 \\
\hline 5 & France & 78 & 51 \\
\hline 6 & Australia & 78 & 51 \\
\hline 7 & US & 89 & 62 \\
\hline 8 & Sweden & 91 & 65 \\
\hline 9 & Ireland & 83 & 58 \\
\hline 10 & Portugal & 76 & 51 \\
\hline 11 & Yemen & 80 & 56 \\
\hline 12 & Belgium & 76 & 52 \\
\hline 13 & Malaysia & 58 & 34 \\
\hline 14 & Japan & 81 & 57 \\
\hline 15 & Estonia & 69 & 46 \\
\hline 16 & Czech Republic & 71 & 48 \\
\hline 17 & Germany & 88 & 67 \\
\hline 18 & UK & 82 & 62 \\
\hline 19 & Taiwan & 74 & 54 \\
\hline
\end{tabular}




\section{Continued}

\begin{tabular}{lccc}
\hline \multicolumn{4}{c}{ Others Countries (Source: Numbeo, 2018) } \\
& Country & $\begin{array}{c}\text { Safety walking alone } \\
\text { during daylight }\end{array}$ & $\begin{array}{c}\text { Safety walking alone during } \\
\text { night }\end{array}$ \\
1 & Madagascar & 71.43 High & 10.71 Very Low \\
2 & Tanzania & 60.42 High & 28.75 Low \\
3 & Thailand & 75.51 High & 50.86 Moderate \\
4 & India & 74.06 High & 50.83 Moderate \\
5 & Malaysia & 55.50 Moderate & 28.93 Low \\
6 & Nigeria & 50.73 Moderate & 35.54 Low \\
7 & Nepal & 82.43 Very High & 49.51 Moderate \\
8 & Pakistan & 64.43 High & 42.64 Moderate \\
\hline
\end{tabular}

the country. As this study showed a number of reasons of urban. Huge population in urban area is a big challenge for local controlling authority, as it created more changes for criminals to engage themselves into criminal activities, although now in developed countries they are trying to control it with different types of security instruments like CCTV camera and with the help of local police system. Unemployment is another factor of crime; unemployed people are easier to get involves in criminal activity as compare to employed person especially in developing countries because such countries are not able to provide unemployed allowance people. Almost half of the world population is living under the rate of poverty. Literature showed poverty is another factor of urban crimes. Political factors directly influence crime rate in urban areas. Bad governance generates inequality among people which lead to unemployment and social inequalities (Ajaegbu, 2012). Thus, it becomes as the most important factor of urban crimes. Criminals take advantages when law enforcement bodies lack in implementation of strong rules and regulations. Research supports that crime-control agencies provide much room for criminals to enhance their activities (Ghani, 2017). Resources are very important for any country for the smooth run of all proper activities in the countries, due to collapsing infrastructure. Many cities in the developing world do not have an infrastructure that is capable of dealing with the massive increases in population. In addition, the governments do not have sufficient funds available to maintain the facilities. Due to such conditions it becomes very easy for ordinary people to buy armed and to get involved into criminal activities. Some of the indictors were explained well in this research.

Furthermore, eight countries from developing world were selected for to check the crime situation over there. Crime level in Madagascar is high and it is increasing from last three years, Madagascar people do not feel secure at home about their belonging. People has armed over there and used for robbery purposes. Situation in Tanzania even more worst, people are not feeling securing at home, robbery rate is high, use of drugs and due to its property crime ratio is increasing and at alarming rate. Thailand situation is better as compare to other countries, but even there is problem related to robbery. As per given data crime 
Table 2. Crime in different countries.

\begin{tabular}{|c|c|c|c|c|c|c|c|c|}
\hline Country & Level of Crime & $\begin{array}{c}\text { Crime } \\
\text { increasing in } \\
\text { the past } 3 \text { years }\end{array}$ & $\begin{array}{c}\text { Worries home } \\
\text { broken and } \\
\text { things stolen }\end{array}$ & $\begin{array}{l}\text { Worries being } \\
\text { mugged or } \\
\text { robbed }\end{array}$ & $\begin{array}{c}\text { Worries car } \\
\text { stolen }\end{array}$ & $\begin{array}{l}\text { Problem people } \\
\text { using or dealing } \\
\text { drugs }\end{array}$ & $\begin{array}{c}\text { Problem } \\
\text { property crimes } \\
\text { such as } \\
\text { vandalism and } \\
\text { theft }\end{array}$ & $\begin{array}{l}\text { Problem violent } \\
\text { crimes such as } \\
\text { assault and } \\
\text { armed robbery }\end{array}$ \\
\hline Madagascar & 78.57 High & 92.86 Very High & 66.67 High & 57.14 Moderate & 53.57 Moderate & 32.14 Low & 64.29 High & 71.43 High \\
\hline Tanzania & 62.50 High & 75.83 High & 61.84 High & 68.75 High & 48.71 Moderate & 53.5 Moderate & 64.58 High & 59.32 Moderate \\
\hline Thailand & 49.95 Moderate & e $64.21 \mathrm{High}$ & 52.17 Moderate & 47.60 Moderate & 41.29 Moderate & 61.58 High & 53.47 Moderate & 50.66 Moderate \\
\hline India & 46.22 Moderate & 58.04 Moderate & 43.54 Moderate & 42.04 Moderate & 39.25 Low & 37.69 Low & 46.54 Moderate & 39.93 Low \\
\hline Malaysia & 64.73 High & 72.33 High & 64.24 High & 66.81 High & 60.33 High & 54.44 Moderate & 66.57 High & 61.53 High \\
\hline Nigeria & 65.15 High & 56.16 Moderate & 59.89 Moderate & 64.44 High & 58.58 Moderate & 61.69 High & 65.88 High & 70.39 High \\
\hline Nepal & 33.00 Low & 36.76 Low & 46.04 Moderate & 37.13 Low & 20.41 Low & 49.75 Moderate & 43.75 Moderate & 33.25 Low \\
\hline Pakistan & 52.20 Moderate & 46.82 Moderate & 43.98 Moderate & 52.19 Moderate & 50.12 Moderate & 48.70 Moderate & 52.05 Moderate & 53.59 Moderate \\
\hline
\end{tabular}

Source: Table generated by author from Numbeo database 2017 and 2018 (Numbeo, 2017, 2018).

situation in India is better which is from low to moderate. Crime rate in Malaysia is in red zone, it increasing from last few years, life is not secure, robbery is high and drug use is moderate. Nigeria situation is not different from other these countries, they are also facing the same situation. Nepal and Pakistan are in the rate of low to moderate Table 2. These all indicators showed that situation in these countries is not better, these all countries in the list of developing countries and maybe they are not able to control it with immediate effect.

\section{Conclusion and Recommendations}

Crime is poison for every nation and countries whatever they are developed or developing one. Present study explained well about crimes, reasons of crimes and crime situation in some areas of world. Situation of crime in developing countries is in dangerous zone. Study showed crime is increasing from last three years which is high. In any society, urban crime prevails that it created unsafe environment, threaten to lives, threaten to belonging and has impact on life quality and economy of the country. Best solution to control crime is the law enforcement agencies that must be proactive rather than reactive. Strong and well planning needed in urban crimes area to save the people belonging. It's government responsibilities to control such situations and provide security to local people as it is a basic human right to live securely and peacefully. Local police and local agencies must be empowered and well equipped. It is also government responsibilities to create more and more employment, there is a positive correlation between crime and unemployment.

\section{Acknowledgements}

I would like to say thanks to China Scholarship Council (CSC) funding authority, Central South University Changsha Hunan China and my supervisor Prof. 
Liu Yideng for his expert and professional supervision. I express gratitude to our families and friends for their unending support.

\section{Conflicts of Interest}

The authors declare no conflicts of interest regarding the publication of this paper.

\section{References}

Ahmed, M., \& Salihu, R. S. (2013). Spatiotemporal Pattern of Crime Using Geographic Information System (GIS) Approach in Dala L.G.A of Kano State, Nigeria. American Journal of Engineering Research, 2, 51-58.

Ajaegbu, A. A. (2012). Rising Youth Unemployment and Violent Crime in Nigeria. American Journal of Social Issues Humanities, 2, 315-321.

Amin, S. (2014). Capitalism in the Age of Globalization: The Management of Contemporary Society. London: Zed Books Ltd.

Dambazau, A. B. (2007). The Nigerian Police and Crime Prevention: Criminology and Criminal Justice. Kaduna: Nigerian Defense Academy Press.

England, M. R., \& Simon, S. (2010). Scary Cities: Urban Geographies of Fear, Difference and Belonging. Social \& Cultural Geography, 11, 201-207. https://doi.org/10.1080/14649361003650722

Ghani, Z. A. (2017). A Comparative Study of Urban Crime between Malaysia and Nigeria. Journal of Urban Management, 6, 19-29. https://doi.org/10.1016/j.jum.2017.03.001

Greenwood, C. (1972). Firearms Control: A Study of Armed Crime and Firearms Control in England and Wales (p. 244). London: Routledge and Kegan Paul.

Habibullah, M. S., Baharom, A. H., \& Tan, K. S. (2013). Crime and Police Personnel in Malaysia: An Empirical Investigation. Prosiding Persidangan Kebangsaan

Harris, J. R., \& Todaro, M. P. (1970). Migration, Unemployment and Development: A Two-Sector Analysis. The American Economic Review, 60, 126-142.

Heyer, J., Roberts, P., \& Williams, G. (1981). Rural Development in Tropical Africa. London: Palgrave Macmillan. https://doi.org/10.1007/978-1-349-05318-6

Hipp, J. R. (2007). Income Inequality, Race, and Place: Does the Distribution of Race and Class within Neighborhoods Affect Crime Rates? Criminology, 45, 665-697. https://doi.org/10.1111/j.1745-9125.2007.00088.x

ICPC (2014). 4th International Report on Crime Prevention and Community Safety (p. 168). Montreal: International Centre for the Prevention of Crime.

Katsina, A. M. (2013). A Contextual Analysis of Party System Formation in Nigeria, 1960-2011. Intellectual Discourse, 21, 221-240.

Knight, J., \& Gunatilaka, R. (2017). Great Expectations? Subjective Well-Being of Rural-Urban Migration in China. Department of Economics, Discussion Paper Series, University of Oxford.

Messner, S. F. (1982). Poverty, Inequality, and the Urban Homicide Rate: Some Unexpected Findings. Criminology, 20, 103-114. https://doi.org/10.1111/j.1745-9125.1982.tb00450.x

Numbeo (2017, 2018). Crime Index. https://www.numbeo.com/crime/rankings.jsp

Patterson, E. B. (1991). Poverty, Income Inequality, and Community Crime Rates. Criminology, 29, 755-776. https://doi.org/10.1111/j.1745-9125.1991.tb01087.x 
Sampson, R. J., \& Groves, W. B. (1989). Community Structure and Crime: Testing Social-Disorganization Theory. American Journal of Sociology, 94, 774-802. https://doi.org/10.1086/229068

Scheingold, S. A. (1995). Politics, Public Policy, and Street Crime. The Annals of the American Academy of Political and Social Science, 539, 155-168. https://doi.org/10.1177/0002716295539001012

Simon, J. (2017). Governing through Crime. In Law and Poverty (pp. 97-115). Abingdon-on-Thames: Routledge.

Soh, M. C. (2012). Crime and Urbanization: Revisited Malaysian Case. Procedia-Social and Behavioral Sciences, 42, 291-299. https://doi.org/10.1016/j.sbspro.2012.04.193

Sohail, M. T., Delin, H., Talib, M. A., Xiaoqing, X., \& Akhtar, M. M. (2014). An Analysis of Environmental Law in Pakistan-Policy and Conditions of Implementation. Research Journal of Applied Sciences, Engineering and Technology, 8, 644-653.

South African Cities Network (SACN) (2017). The State of Urban Safety in South Africa, Urban Safety Reference Group.

Tenibiaje, D. J. (2010). Personality and Development of Crime in Nigeria. Current Research Journal of Social Sciences, 2, 214-219.

Todaro, M. P. (1976). Urban Job Expansion, Induced Migration and Rising Unemployment: A Formulation and Simplified Empirical Test for LDCs. Journal of Development Economics, 3, 211-225. https://doi.org/10.1016/0304-3878(76)90049-3

Tretter, E. (2013). Sustainability and Neoliberal Urban Development: The Environment, Crime and the Remaking of Austin's Downtown. Urban Studies Journal, 1-16. https://doi.org/10.1177/0042098013478234

Usman, U., Yakubu, M., \& Bello, A. Z. (2012). An Investigation on the Rate of Crime in Sokoto State Using Principal Component Analysis. Nigerian Journal of Basic and Applied Science, 20, 152-160. 